\title{
ESTIMATES OF GENETIC PARAMETERS FOR FRUIT YIELD AND QUALITY IN CUSTARD APPLE PROGENIES ${ }^{1}$
}

\author{
PAULO SÉRGIO LIMA E SILVA ${ }^{2}$, RAFAELA PRISCILA ANTONIO ${ }^{3}$, KENY HENRIQUE MARIGUELE $^{4}$, \\ KATHIA MARIA BARBOSA E SILVA ${ }^{5}$, LIDIANE KELY DE LIMA ${ }^{3}$, JÚLIO CÉSAR DO VALE SILVA ${ }^{3}$
}

ABSTRACT - Apparently, there are no custard apple cultivars defined for the northeastern region of Brazil. The establishment of breeding programs aimed at the selection of types from productive locations for later cloning is desirable. This work's objective was to evaluate the yield (during the first three crops) and quality (first crop) of fruits from 20 half-sibling custard apple tree progenies, selected from home orchards. An additional objective was to estimate genetic parameters for the traits evaluated. A micro sprinkling-irrigated experiment was conducted in Mossoró-RN, Brazil, as random blocks with five replications. In characteristics evaluated for periods longer than a year (diameter, height and mean weight of fruits, number of fruits ha ${ }^{-1}$ and fruit yield $\left(\mathrm{kg} \mathrm{ha}^{-1}\right)$, and a split-plot design was adopted, with progenies considered as plots and annual cropping seasons as subplots. The best progenies in terms of fruit yield (A3 and A4) are not necessarily the best for fruit dimensions and fruit mean weight (A2, FE4, JG1, JG2, SM1, SM7, and SM8). These progenies show great potential to be used in future studies on crosses or on vegetative propagation. In this regard, progeny JG2 should be highlighted as promising in terms of yield and fruit size. The progenies are not different with regard to percentages (in relation to mean fruit mass) of pericarp, endocarp, seeds, and receptacle, in the fruit, and fruit volume, number of seeds/fruit, and total soluble solids content in the fruit pulp, but progeny FE4 presents higher total titratable acidity in the fruit pulp. Narrow-sense heritability estimates were relatively high for all characteristics in which there was variability between progenies, with higher values for number of fruits ha $\mathrm{h}^{-1}(80 \%)$ and fruit yield (78 \%). Relatively high coefficients of genotypic variation (around 20\%) were observed for number of fruits $\mathrm{ha}^{-1}$ and fruit yield, with lower values for the other characteristics. There were positive genotypic and phenotypic correlations between fruit diameter (FD) and fruit height, FD and mean fruit weight, and number of fruits ha' ${ }^{-1}$ and fruit yield.

Index Terms: Annona squamosa L., bullock's heart, sweetsop, heritability, genotypic correlation

\section{ESTIMATIVAS DE PARÂMETROS GENÉTICOS DO RENDIMENTO E DA QUALIDADE DO FRUTO DE PROGÊNIES DA PINHEIRA}

RESUMO - Aparentemente não existem cultivares de pinheira definidas para o Nordeste brasileiro. É desejável o estabelecimento de programas de melhoramento, visando à seleção de tipos de locais produtivos para posterior clonagem. $\mathrm{O}$ objetivo do presente trabalho foi avaliar o rendimento (nas três primeiras safras) e a qualidade (na primeira safra) dos frutos de 20 progênies de meias-irmãs de pinheiras, selecionadas em pomares caseiros. Um objetivo adicional foi a estimação de parâmetros genéticos para as características avaliadas. O experimento, irrigado por microaspersão, foi realizado em Mossoró-RN, em blocos ao acaso, com cinco repetições. Nas características avaliadas em três safras (diâmetro, altura e peso médio de frutos, $\mathrm{n}^{\circ}$. de frutos $\mathrm{ha}^{-1}$ e rendimento de frutos $\left(\mathrm{kg}\right.$ ha $\left.{ }^{-1}\right)$, adotou-se um delineamento de parcelas subdivididas (progênies nas parcelas). As melhores progênies em termos de rendimento de frutos (A3 e A4) não são necessariamente as melhores quanto às dimensões e peso médio dos frutos (A2, FE4, JG1, JG2, SM1, SM7, e SM8). Essas progenies apresentam grande potencial para serem usadas em trabalhos futuros como genitores em cruzamentos ou para propagação vegetativa. Neste sentido, merece destaque a progênie JG2, promissora em termos de rendimento e tamanho do fruto. As progenies não diferem quanto às percentagens (em termos de peso do fruto) de pericarpo, endocarpo, semente e receptáculo no fruto, nem quanto ao volume do fruto, número de sementes/fruto e teor de sólidos solúveis totais da polpa do fruto, mas a progênie FE4 apresentou polpa com maior acidez titulável total. As estimativas da herdabilidade no sentido restrito foram relativamente elevadas em todas as características nas quais existiu variabilidade entre progênies, com maiores valores no número de frutos ha ${ }^{-1}(80 \%) \mathrm{e}$ rendimento de frutos ( $78 \%$ ). Valores relativamente elevados (em torno de $20 \%$ ) do coeficiente de variação genotípica foram observados no número de frutos $\mathrm{ha}^{-1}$ e rendimento de frutos, com menores valores nas outras características. Foram positivas as correlações genotípicas e fenotípicas entre diâmetro do fruto (DF) e altura do fruto, DF e peso médio do fruto, e número de frutos ha ${ }^{-1}$, e rendimento de frutos.

Termos para indexação: Annona squamosa L., pinha, ata, fruta-do-conde, herdabilidade, correlação genotípica.

(Trabalho 64-06). Recebido em :16-05-2006. Aceito para publicação em : 04-09-2007.

2 Professor Adjunto da Universidade Federal Rural do Semi-Árido (UFERSA), Dep. Ciências Vegetais, Br-110, km 47, Bairro Pres. Costa e Silva, CEP 59625-900 Mossoró, RN, Brazil. E-mail: paulosergio@ufersa.edu.br. CNPq Fellow

${ }^{3}$ Estudante de agronomia da UFERSA. E-mail: rafapris@yahoo.com.br.

${ }^{4}$ Estudante de Doutorado em Genética e Melhoramento. Universidade Federal de Viçosa. 37500-000 Viçosa-MG. E-mail: kmariguele@hotmail.com

${ }_{5}^{5}$ Professora Adjunta. Departamento de Biologia, UERN, Faculdade de Ciências Biológicas e Naturais, CP 130, Mossoró-RN, CEP 59625-910. E-mail: kathiafanat@uern.br. 


\section{INTRODUCTION}

Irrigated fruit cropping is one of the most important agricultural activities in the Agricultural Center of MossoróAssu, Rio Grande do Norte, Brazil. There has been an increasing interest by fruit growers in the cultivation of new species.

Among fruit trees that became interesting to fruit growers, the custard apple tree (Annona squamosa L.) should be highlighted since it is well adapted to the conditions of the SemiArid Region (Maia et al., 1986) and because it yields fruits with a very sweet and fragrant pulp, and a pleasant and exotic flavor, considered the most desirable characteristics of custard apple. The custard apple plant is a very branched-out tree 4 to $6 \mathrm{~m}$ tall. The fruit is a round, ovoid, spherical, or cordiform syncarp, 5 to $10 \mathrm{~cm}$ in diameter. The custard apple is a fruit tree native to Central America and the northeastern part of South America; it is grown in tropical regions, at low and medium elevations (Purseglove, 1968). In Brazil, it is explored in a number of states of the Brazilian Northeast Region, and in a few other states of other regions (São José et al., 1997). In the regions where it is exploited, custard apples are sold mainly for fresh consumption or for the preparation of juices and ice cream (Leal, 1990).

Although it is a fruit with large acceptance in the consumer market, apparently there are no defined custard apple cultivars in Brazil, except for "seedless custard apple", originated from a somatic mutation, which produces parthenocarpic fruits (Manica, 1994). The lack of cultivars is a consequence of the small number of works on genetic breeding. In fact, the shortage of superior clones is one of the most important obstacles to custard apple exploiting in some Brazilian Northeastern states (Bandeira \& Sobrinho, 1997; Lederman \& Bezerra, 1997). In this respect, the establishment of breeding programs targeted at the selection of types from productive locations for later cloning would be desirable (Freitas \& Couto, 1997).

As a consequence of the small number of works on custard apple breeding, there are few reports in the literature about custard apple genotype evaluations. The studies conducted so far have demonstrated variation among genotypes with regard to fruit yield and other characteristics, such as plant height, stem diameter, and crown diameter (Carvalho et al., 2000). No results about assessment of different genotypes for fruit quality were found in the consulted literature.

Estimates of genetic parameters are necessary so that the selection of superior genotypes can be optimized and alternative breeding strategies evaluated (Hardner et al., 2001). The key genetic parameters are: narrow sense of heritability, broad-sense of heritability, the phenotypic correlation and genetic correlation (Falconer, 1989). Narrow sense of heritability is the proportion of phenotypic variation that is due to differences in additive genetic effects, which are the effects that breeding can most easily exploit. Broad sense of heritability is the proportion of phenotypic variation that is due to total (additive and non-additive) genetic effects and is important in crops such as custard apple where clonal propagation of elite individual genotypes can exploit this source of variation. Phenotypic correlation measures how different traits co-vary across phenotypes. A genetic correlation measures the degree to which different traits are controlled by the same gene or genes that are closely linked. In addition, correlations can be used to measure the similarity in performance in different environments and the similarity in performance at different ages. Genetic and phenotypic correlations are used to predict how selection on one trait influences responses in another trait (Hardner et al., 2001).

The increased demand for custard apple trees has encouraged the collection, characterization and evaluation of germplasm, aimed at obtaining cultivars (Sousa et al., 2001). This work's objective was to evaluate, during the first three crops, the yield and quality of fruits from 20 half-sibling custard apple tree progenies, collected from home orchards. An additional objective was to estimate genetic and phenotypic parameters for the traits evaluated.

\section{MATERIAL AND METHODS}

The experiment was conducted at the "Rafael Fernandes" Experimental Farm (latitude $5^{\circ} 11^{\prime} \mathrm{S}$, longitude $37^{\circ} 20^{\prime} \mathrm{W}$, and $18 \mathrm{~m}$ elevation). Data on the climatic conditions during the period when the experiment was conducted can be obtained from http:/ \www.ufersa.edu.br.

The progenies were obtained in home orchards in the municipal districts of Aracati-CE, Mossoró-RN, and Serra do Mel$\mathrm{RN}$. Based on plant health and vigor and their apparent fruit yield, 25 matrices were selected. The seeds were sown in black perforated plastic bags, $32 \mathrm{~cm}$ tall and $25 \mathrm{~cm}$ in diameter. The bags were filled with a substrate consisting of $1,800 \mathrm{~L}$ cattle manure, 3,600 L Red-Yellow Argisol (RYA) (EMBRAPA, 1999), $1,080 \mathrm{~g}$ potassium chloride, and 1,620 $\mathrm{g}$ single superphosphate. At 23 and 25 days after sowing, the seedlings received an application of the product Mastermins (with the following percentage contents: $14 \mathrm{~N}, 9 \mathrm{P} 2 \mathrm{O} 5,6 \mathrm{~K} 2 \mathrm{O}, 08 \mathrm{~S}, 1.5 \mathrm{Mg}, 2 \mathrm{Zn}, 0.1$ $\mathrm{B}, 1.5 \mathrm{Mn}$, and $0.05 \mathrm{Mo}$ ). Among the 25 progenies, 20 were selected based on their vigor.

The planting pits were opened in October $/ 00$, measuring $60 \mathrm{~cm} \times 60 \mathrm{~cm} \times 60 \mathrm{~cm}$, at a spacing of $5.0 \mathrm{~m} \times 4.5 \mathrm{~m}$. The experimental soil was classified according to the Brazilian Soil Classification System as Eutrophic Red-Yellow Podzolic (EMBRAPA, 1999) and as a Ferric Lixisol according to the Soil Map of the World (FAO, 1988). Analysis of this soil showed the following results: $\mathrm{pH}=$ $6.6, \mathrm{Ca}+\mathrm{Mg}=4.20 \mathrm{cmol}_{\mathrm{c}} \mathrm{dm}^{-3}, \mathrm{P}=25 \mathrm{mg} \mathrm{dm}^{-3}, \mathrm{~K}=0.28 \mathrm{cmol}_{\mathrm{c}} \mathrm{dm}^{-3}$, $\mathrm{Na}=0.07 \mathrm{cmol}_{\mathrm{c}} \mathrm{dm}^{-3}, \mathrm{Al}=0.02 \mathrm{cmol}_{\mathrm{c}} \mathrm{dm}^{-3}$, and organic matter $=$ $10.40 \mathrm{~g} \mathrm{~kg}^{-1}$. Eighteen liters of rotted cattle manure, in addition to $240 \mathrm{~g}$ ammonium sulfate $\left(80 \mathrm{~kg} \mathrm{~N} \mathrm{ha}^{-1}\right), 2,340 \mathrm{~g}$ single superphosphate $\left(80 \mathrm{~kg} \mathrm{P}_{2} \mathrm{O}_{5} \mathrm{ha}^{-1}\right)$ and $60 \mathrm{~g}$ potassium chloride $\left(60 \mathrm{~kg} \mathrm{~K}_{2} \mathrm{O} \mathrm{ha}^{-1}\right)$ per pit were used as planting fertilization. The above-mentioned fertilization, with the exception of manure, was repeated on the twentieth of February, April, June, August and October, from 2001 to 2004.

The progenies were evaluated in a random block design with five replicates and four plants per plot, irrigated with a micro sprinkler system. In characteristics evaluated for periods longer than a year, a split-plot design was adopted, with progenies 
considered as plots and annual cropping seasons as subplots. Each custard apple tree was associated with a micro sprinkler placed near the stem, with a flow of approximately $50 \mathrm{~L} \mathrm{~h}^{-1}$. Each plant received about $100 \mathrm{~L}_{\text {water day }}{ }^{-1}, 3$ days a week. Due to water limitations, a greater amount of water could not be applied. Yield and fruit quality were evaluated during the period from September 2001 to February 2004. The fruits were harvested every two days during the entire year, and were weighed and measured. Fruit quality was evaluated in fifteen fruits plot $^{-1}$, by percentage values (based on fruit weight) of pericarp, seeds, pulp plus pericarp, fruit volume, total soluble solids content (TSST), $\mathrm{pH}$, total titratable acidity (TTA) and number of seeds fruit ${ }^{-1}$. Fruit volume was determined with a Beaker. The pulp was ground in a household food processor, and the juice was extracted with a nylon tissue for the chemical analyses. TTA was determined by using a $10 \mathrm{~mL}$ pulp aliquot, added of $40 \mathrm{~mL}$ distilled water and 4 droplets alcohol-phenolphthalein at $1 \%$. Titration was performed until the end point with a previously standardized $0.1 \mathrm{~N} \mathrm{NaOH}$ solution. Results were expressed as \% citric acid/ 100g pulp. TSST was determined with three replicates by refractometry, with a model PR-100, Palette digital refractometer (Attago Co., LTD, Japan), with automatic temperature compensation, according to AOAC specifications (1992). PH was obtained with a Tecnal model Tec- 2 measuring device, using a $10 \mathrm{~mL}$ aliquot from the homogenized sample.

Either total or mean values were used in the analysis of variance (Zar, 1999), in the case of characteristics evaluated by more than one sampling unit. The means were compared at $5 \%$ probability by Skott-Knott test (1974).

The statistical analyses were performed using software GENES developed by Universidade Federal de Viçosa (Cruz, 2006). The following model was adopted for characteristics evaluated in a single year: $Y_{i j}=\mu+G_{i}+B_{j}+E_{i j}$, where $Y_{i j}=$ observation for the plot that received progeny $\mathrm{i}$ in block $\mathrm{j} ; \mu=$ fixed effect of the overall mean for the experiment, with $\mathrm{E}[\mu]=\mu$ and $\operatorname{Var}[\mu]=0 ; G_{i}=$ random effect of progeny $\mathrm{i}$, with $\mathrm{i}=1,2, \ldots, \mathrm{I}$ and $p_{i} \cap$ NID $\left(0, \sigma_{p}^{2}\right) ; B_{j}=$ random effect of block $\mathrm{j}$, with $\mathrm{j}=1.2$, $\ldots, \mathrm{J}$ and $\mathrm{b}_{\mathrm{k}} \cap \operatorname{NID}\left(0, \sigma_{B}^{2}\right)$; and $E_{i j}=$ random effect of the experimental error associated with observation $y_{i k}$, with $e_{i k} \cap$ NID $\left(0, \sigma^{2}\right)$. For characteristics evaluated during three years, the treatment design adopted consisted of split-plots with random $\mathrm{G}$ and fixed A, according to the model $Y_{i j k}=\mu+B_{j}+G_{i}+(B G)_{i j}+$ $A_{k}+G A_{i k}+E_{i j k}$, where: $Y_{i j k}=$ observation for the experimental unit that received progeny $\mathrm{i}$ in block $\mathrm{j}$, in harvest $\mathrm{k}$; $\mu$ : fixed effect of the overall mean for the experiment, with $\mathrm{E}[\mu]=\mu$ and $\operatorname{Var}[\mu]=0$; $B_{i}$ : random effect of block $\mathrm{j}$, with $\mathrm{j}=1.2, \ldots, \mathrm{J}$ with $b_{j} \cap \operatorname{NID}\left(0, \sigma_{B}^{2}\right)$ $; G_{j}=$ random effect of progeny; with $\mathrm{i}=1.2, \ldots$, I and $g_{i} \cap$ NID ( $\left.0, \sigma_{P}^{2}\right) ;(B G)_{i j}=$ random effect of the interaction between block $\mathrm{j}$ and progeny i; $A_{k}=$ fixed effect of harvest $\mathrm{k}$, with $\mathrm{k}=1, \ldots, \mathrm{I}$; $(G A)_{i k}=$ random effect of the interaction between progeny $\mathrm{i}$ and harvest k, with $g a_{i k} \cap \operatorname{NID}\left(0, \sigma_{P A}^{2}\right) ; E_{i j k}=$ random effect of the average experimental errors associated with observation $Y_{i j k}$, with $E_{i j k} \cap \operatorname{NID}\left(0, \sigma^{2}\right)$

The variance component estimates were obtained based on the moment's method, which consists in making the mathematical expectations of the mean squares equal to their corresponding mean square values. Estimations included: genetic variances between progenies in the data analyses for one harvest $\left(\sigma_{p}^{2}{ }^{*}\right)$ and three harvests $\left(\sigma_{p}^{2}\right)$; variance of the progenies $\times$ harvest interaction in the data analysis of three harvests $\left(\sigma_{p c}^{2}\right)$; and phenotypic variance between progeny means in the analyses of one harvest $\left(\sigma^{2} \bar{F}\right)$ and three joint harvests $\left(\sigma_{F}^{2}\right)$. In addition to these variance components, we estimated narrow-sense of heritability $\left(h^{2}\right)$, genetic coefficient of variation $\left(\mathrm{CV}_{\mathrm{g}}\right)$, and $\mathrm{CV}_{\mathrm{g}} /$ $\mathrm{CV}_{\mathrm{e}}$ ratio. Coefficients of correlation were estimated according to Cruz \& Regazzi (1994).

\section{RESULTS AND DISCUSSION}

Genetic variability was observed between progenies for all fruit-yield-related characteristics (Table 1). A harvest effect also occurred for all characteristics, with the exception mean weight of fruit. However, the interaction effect of progenies $\times$ harvests, also observed by other authors (Hardner et al., 2001), only existed for number of fruits ha-1 and fruit yield (Table 1). With regard to qualitative fruit characteristics, genetic variability between progenies only occurred for total titratable acidity (Table 2), differently from observations made in cupuaçu trees, where genetic variability was verified between progenies with regard to several attributes of the pericarp, pulp, and seeds (Machado et al., 2002). Therefore, in a custard apple tree breeding program, these two characteristics are harder to work with, due to the existence of an interaction between progenies and cropping seasons. Studying the interaction between progenies $\times$ harvests is particularly interesting in perennial crops, since its existence indicates a differential behavior of progenies between cropping seasons, and consequently a low repeatability of the trait. Therefore, it is recommended that selection of the best progenies be made based on information spanning several cropping seasons, looking for genotypes with greater production stability (Machado et al., 2002).

The coefficient of experimental variation values $(\mathrm{CV})$ for number and weight of fruits, per hectare, are quite high (Table 1). This may be due to at least three reasons relating to experimental precision, although the experimental mean can obviously influence the $\mathrm{CV}$ value. First, the soils in the region are relatively heterogeneous. Second, the area occupied by each block was relatively large, because of the number of progenies evaluated and the row spacing required by the crop. This may have resulted in loss of local control to a certain extent, conditioned by the random block design adopted. Finally, using only four plants to represent one progeny in each plot may not have been the most adequate approach, since this is an allogamous species. Despite these reasons, the evaluation was effective in separating different progenies for yield and other fruit characteristics. In order to achieve greater precision in future assays, it might be advisable to use a larger number of plants/plot and reduce the number of progenies evaluated.

Heritability estimates were relatively high for all characteristics in which there was variability between progenies (Tables 1 and 2), with higher values for number of fruits ha' ${ }^{-1}$ and fruit yield (Table 1). Like other authors (Gonçalves et al., 1998), it 
is important to point out that when obtaining heritability estimates, we considered the absence of endogamy in the base populations under study as an indispensable condition, as preconized by Vencovsky (1969). The occurrence of selffertilization or a restriction of the actual size of the population in half-sibling progeny tests may increase genetic variance estimates. Therefore, the genetic parameter estimates obtained in the progenies here evaluated might be overestimated if endogamy occurred in those progenies. It is still important to note that heritability is a property of a character only for the population and the environmental circumstance to which the individuals are subjected (Falconer, 1981). The value of the heritability estimate depends on the magnitude of all the components of variance, and a change in any one of these will affect it. All the genetic components are influenced by gene frequencies and may therefore differ from one population to another, according to the past history of the population (Daoyu et al., 2002). The lowest heritability estimate (47\%) was observed for fruit diameter (Table 1), although even lower values (from $32 \%$ to $43 \%$ ) were observed in guava characteristics (Dinesh \& Yadav, 1998). Three possible explanations for low values for narrow sense heritability are: genetic homogeneity of the sample population investigated; low levels of additive gene effects relative to dominance/epistatic effects in the expression of these traits, or large effect of non-genetic (environmental) variability (Hansche et al., 1972). Whatever the case, in breeding practice such characters cannot be improved efficiently by individual selection, which operates through improving the average genetic worth of successive generations (Daoyu et al., 2002).

Relatively high coefficients of genotypic variation (around $20 \%$ ) were observed for number of fruits ha $^{-1}$ and fruit yield (Table 1), with lower values (from $1 \%$ to $7 \%$ ) for the other characteristics (Tables 1 and 2). Estimates of this coefficient for cupuaçu characteristics ranged from 6\% to 37\% (Machado et al, 2002). The $\mathrm{CV}_{\mathrm{g}} / \mathrm{CV}_{\mathrm{e}}$ ratio is known as variation index; the closer it is to one, the better the situation is for the breeder to practice selection (Vencovsky \& Barriga, 1992). In the present work (Tables 1 and 2), this ratio varied from 0.22 (fruit diameter) to 0.60 (total titratable acidity), therefore being more favorable in total titratable acidity. As to number of fruits $\mathrm{ha}^{-1}$ and fruit yield, an intermediate value (0.45) was obtained for that ratio.

There were positive genotypic and phenotypic correlations between fruit diameter (FD) and fruit height, FD and mean fruit weight, and number of fruits ha ${ }^{-1}$ and fruit yield (Table 3 ). Positive correlations between dimensions and mean fruit weight were observed in guava by other authors (Dinesh \& Yadav, 1998). Positive values indicate that the two characters are benefited or damaged for the same causes of variations (Cruz, 2005). Genetic correlation among characteristics may be due to pleiotropy, although linkage disequilibrium is also a cause of correlation, albeit transitory. The degree of correlation due to pleiotropy expresses the extent which two characteristics are controlled by same genes, but pleiotropic genes do not necessarily cause an observable correlation due to dependence on allele frequencies as well. The phenotypic correlation is a nonadditive combination of both the genetic and environmental correlations.

The fruit yield of progenies, expressed in terms of $\mathrm{kg} \mathrm{ha}^{-1}$ or number of fruits $\mathrm{ha}^{-1}$, was not independent from cropping season, as mentioned (Tables 1 and 4). When genotypes behave differently in different cropping seasons, one option breeders have is to identify those progenies that show the least fluctuation in the various cropping seasons. With respect to fruit yield ( $\mathrm{kg}$ $\mathrm{ha}^{-1}$ ), there were no differences between progenies during cropping season 1 . In cropping season 2, progenies A3, A4 and JG2 showed the highest means. In cropping season 3, progenies M, A5, FE1, FE3, FE4, JG3, SM1, and SM8 were the least productive. With respect to number of fruits/ha, there were no differences between progenies during cropping season 1 . In cropping season 2, progenies A3 and A4 were the best. In cropping season 3, progeny A3 was again the best, although it did not differ from another ten progenies. Progenies A3 and A4 were the best, simultaneously, in the three cropping seasons, with regard to both characteristics. Therefore, it seems reasonable to admit that in general progenies A3 and A4 shows the most promising behavior when both characteristics are considered, in the three cropping seasons.

Few studies (Carvalho et al., 2000) were found in the consulted literature dealing with custard apple tree genotype assessment, so that the comparison of results obtained in the present study with those from other authors is limited. For example, in the papers available in the literature (Carvalho et al., 2000), a joint analysis for several cropping seasons has not been presented. The fruit yields observed in the present study have a similar magnitude as those found by other authors (São José et al., 1997), who observed productivities of up to $2,000 \mathrm{~kg} / \mathrm{ha}$. This low yield could be attributed to the lack of irrigation in periods of greater water deficit and to the lack of better management practices. In another paper (Carvalho et al, 2000), variations from $2,050 \mathrm{~kg} / \mathrm{ha}$ to $3,258 \mathrm{~kg} / \mathrm{ha}$ were found. These higher yields could be due, at least in part, to higher plant age (seven years) in comparison with the age of plants in the present study (four years).

Progenies A2, FE4, JG1, JG2, SM1, SM7, and SM8 simultaneously showed the highest means for fruit diameter, height, and mean weight (Table 4). Therefore, the best progenies in terms of fruit yield (A3 and A4) are not necessarily the best for fruit dimensions and fruit mean weight. Among the progenies that stood out for fruit dimensions and fruit mean weight, JG2 showed the best behavior in terms of fruit weight and number per hectare, in the three cropping seasons. It seems reasonable to accept that, if interest is placed on a higher number of fruits, progenies A3 and A4 are desirable (Table 2), while if interest is on larger fruits (Table 3), although in small numbers, progeny JG2 should be preferred.

The mean fruit dimensions observed in this paper are in general slightly higher than those obtained by other authors (Holschuh et al., 1988; Maia et al., 1986), but have a similar magnitude as those found by Rego et al. (1989). It is interesting to point out that some authors (Holschuh et al., 1987) verified that height in "ripe" custard apples was significantly smaller 
than in "half-ripe" fruits; the same occurred with mean diameter, although the authors did not provide an explanation for such observation. Values ranging from $137 \mathrm{~g}$ to $393 \mathrm{~g}$ in fruits purchased at the market, which therefore must have been selected for larger size, were obtained by other authors (Maia et al., 1986).

The evaluated progenies were not different with regard to the percentages of pericarp, endocarp, seeds, and receptacle, calculated based on fruit weight, nor with regard to fruit volume and number of seeds per fruit, total soluble solids content, and $\mathrm{pH}$ in the fruit pulp (Tables 2 and 6). In most selections, the pulp is the main fruit constituent, followed by the rind + peduncle, and finally the seed (Dantas et al., 1991), which is confirmed, by some authors (Maia et al., 1986). However, several other authors (Holschuh et al, 1988; Rego et al., 1989) verified, as in the present study, that most times the rind (pericarp) was the main fruit constituent, followed by the pulp, seeds, and peduncle (pedicel). Fruit volume varied from $179.0 \mathrm{~mL}$ to $219.2 \mathrm{~mL}$, with an average of $203.6 \mathrm{~mL}$. Therefore, the fruits produced in this work were larger in volume than in other assessments (Holschuh et al., 1988). The mean number of seeds per fruit varied from 31.0 to 41.4; this variation was narrower than the variation of 11.1 to 80.4 seeds fruit $^{-1}$ (Dantas et al., 1991). Again, with regard to total soluble solids content, the observed variation of $23.9^{\circ} \mathrm{B}$ to $25.7^{\circ} \mathrm{B}$ was smaller than the variation observed by other researchers (Dantas et al., 1991). On the other hand, $\mathrm{pH}$ varied from 5.39 to 5.58 .
These values are higher than the mean values observed by some authors (Maia et al., 1986; Rego et al., 1989), but have similar magnitude as those observed by others (Holschoh et al., 1988). The TTA determination values ranged from $0.21 \%$ (Maia et al., 1986) to $0.58 \%$ (Rego et al., 1989), while in the present work TTA varied from $0.16 \%$ to $0.25 \%$, with a mean of $0.21 \%$; the smallest mean was shown by progeny FE4 (Table 5). In spite of the TTA variation, there were no $\mathrm{pH}$ differences between progenies. This fact is probably due to the buffer capacity of some juices, which allow great variations in acidity to occur, without appreciable $\mathrm{pH}$ variations.

The differences between fruit characteristics observed in the present work (Tables 4, 5 and 6) and those obtained by other authors are obviously due to the different custard apple trees evaluated, as well as to the edaphic-climatic and management conditions to which the plants were exposed.

It is important to point out that, in the present work, the plants of each progeny were harvested individually. Therefore, the possibility exists that the most promising progenies or plants are used as parents in crosses, or are vegetative propagated. In this respect, it is worth to mention that progeny JG2 was among those that yielded the largest fruits (Table 4), and only differed from the most productive progenies in number of fruits/ha during the 2002/2003 cropping season (Table 5).

TABLE 1 - Analysis of variance summary and estimates for the coefficient of experimental variation $\left(\mathrm{CV}_{\mathrm{e}}\right)$, variance genetic $\left(\sigma_{\mathrm{g}}^{2}\right)$, progenies $\mathrm{x}$ cropping seasons variance, narrow-sense heritability $\left(\mathrm{h}_{\mathrm{r}}^{2}\right)$, coefficient of genetic variation $\left(\mathrm{CV}_{\mathrm{g}}\right)$, and $\mathrm{CV}_{\mathrm{g}} / \mathrm{CV}_{\mathrm{a}}$ ratio for diameter, height and mean weight of fruits, number of fruits ha ${ }^{-1}$ and fruit yield $\left(\mathrm{kg} \mathrm{ha}^{-1}\right)$ from custard apple progenies in three cropping seasons ${ }^{1}$.

\begin{tabular}{|c|c|c|c|c|c|c|}
\hline \multirow[t]{3}{*}{ Source of variation } & \multirow{3}{*}{$\begin{array}{l}\text { Degrees } \\
\text { of } \\
\text { freedon }\end{array}$} & \multicolumn{5}{|c|}{ Characteristics } \\
\hline & & $\begin{array}{c}\text { Fruit } \\
\text { diameter }\end{array}$ & Fruit height & $\begin{array}{c}\text { Mean weight } \\
\text { of fruit }\end{array}$ & $\begin{array}{c}\text { Number of } \\
\text { fruits } \mathrm{ha}^{-1} \\
\end{array}$ & $\begin{array}{c}\text { Fruit yield } \\
\left(\mathrm{kg} \mathrm{ha}^{-1}\right)\end{array}$ \\
\hline & & \multicolumn{5}{|c|}{ Mean squares estimates ${ }^{1}$} \\
\hline Blocks & 4 & 0.1990 & 0.1256 & 798.39 & 25139348.9 & 998197.2 \\
\hline Genotypes (G) & 19 & $0.2718^{*}$ & $0.2608^{* *}$ & $1385.08^{* *}$ & $10672841.6^{* *}$ & $412566.7^{* *}$ \\
\hline Error a & 76 & 0.1433 & 0.0921 & 551.09 & 2129949.3 & 90548.3 \\
\hline Environments (E) & 2 & $3.7901^{*}$ & $5.4557^{*}$ & $88.58^{\mathrm{ns}}$ & $547209758.9^{* *}$ & $21836936.0^{* *}$ \\
\hline $\mathrm{G} \times \mathrm{E}$ & 38 & $0.2032^{\mathrm{ns}}$ & $0.1697^{\mathrm{ns}}$ & $816.38^{\mathrm{ns}}$ & $3647783.1^{* *}$ & $134226.9^{* *}$ \\
\hline Error b & 160 & 0.1930 & 0.1545 & 668.64 & 2004247.9 & 76983.1 \\
\hline \multicolumn{2}{|l|}{ Statistics } & \multicolumn{5}{|c|}{ Estimates } \\
\hline \multicolumn{2}{|l|}{ Means } & 8.1 & 7.3 & 204.58 & 3566.2 & 724.4 \\
\hline \multicolumn{2}{|l|}{$\begin{array}{l}\text { Coefficient of experimental } \\
\text { variation (CVa, plots) }(\%)\end{array}$} & 5.3 & 5.1 & 12.4 & 45.8 & 44.5 \\
\hline \multicolumn{2}{|l|}{$\begin{array}{l}\text { Coefficient of experimental } \\
\text { variation }(\mathrm{CVb} \text {, subplots })(\%)\end{array}$} & 5.5 & 5.4 & 12.6 & 39.7 & 38.3 \\
\hline \multicolumn{2}{|l|}{ Genetic parameters } & \multicolumn{5}{|c|}{ Estimates } \\
\hline \multicolumn{2}{|l|}{$\begin{array}{l}2 \\
g\end{array}$} & 0.0086 & 0.0112 & 55.60 & 569526.2 & 21467.9 \\
\hline \multicolumn{2}{|l|}{$\begin{array}{l}g \\
2\end{array}$} & 0.0014 & 0.0020 & 19.70 & 219138.0 & 7632.5 \\
\hline \multicolumn{2}{|l|}{$\mathrm{h}_{r}^{2}(\%)$} & 47.28 & 64.66 & 60.21 & 80.0 & 78.1 \\
\hline \multicolumn{2}{|l|}{$\mathrm{CV}_{\mathrm{g}}(\%)$} & 1.15 & 1.46 & 3.64 & 21.2 & 20.23 \\
\hline \multicolumn{2}{|l|}{$\mathrm{CV}_{\mathrm{g}} / \mathrm{CV}_{\mathrm{a}}$} & 0.22 & 0.29 & 0.29 & 0.46 & 0.45 \\
\hline
\end{tabular}

ns, ${ }^{* *},{ }^{*}$ Corresponding effect non-significant and significant at $5 \%$ and $1 \%$ probability by the $\mathrm{F}$ test, respectively. 
TABLE 2 - Analysis of variance summary and estimates for the coefficient of experimental variation $\left(\mathrm{CV}_{\mathrm{e}}\right)$, phenotypic variance $\left(\sigma_{\bar{F}}^{2}\right)$, genetic variance $\left(\sigma_{g}^{2}\right)$, narrow-sense heritability $\left(\mathrm{h}_{\mathrm{r}}^{2}\right)$, coefficient of genetic variation $\left(\mathrm{CV}_{\mathrm{g}}\right)$, and $\mathrm{CV}_{\mathrm{g}} / \mathrm{CV}_{\mathrm{e}}$ ratio for percentages (in relation to mean fruit mass) of pericarp, endocarp, seeds, and receptacle, in the fruit, and fruit volume, number of seeds fruit ${ }^{-1}$, and total soluble solids content and total titratable acidity in the fruit pulp of custard apple tree half-sibling progenies

\begin{tabular}{|c|c|c|c|c|c|c|c|c|c|c|}
\hline \multirow[t]{2}{*}{$\begin{array}{l}\text { Source of } \\
\text { variation }\end{array}$} & \multirow[t]{2}{*}{$\begin{array}{c}\text { Degrees } \\
\text { of } \\
\text { freedon }\end{array}$} & $\begin{array}{l}\text { Pericarp } \\
(\%)\end{array}$ & $\begin{array}{c}\text { Endocarp } \\
(\%)\end{array}$ & $\begin{array}{c}\text { Seeds } \\
(\%)\end{array}$ & $\begin{array}{c}\text { Receptacle } \\
(\%)\end{array}$ & $\begin{array}{c}\text { Fruit } \\
\text { volume } \\
(\mathrm{ml})\end{array}$ & $\begin{array}{c}\begin{array}{c}\text { Number } \\
\text { of seeds/ } \\
\text { fruit }\end{array} \\
\end{array}$ & $\begin{array}{c}\text { Total soluble } \\
\text { solids content } \\
\left({ }^{\circ} \mathbf{B}\right)\end{array}$ & pH & $\begin{array}{c}\text { Total } \\
\text { titratable } \\
\text { acidity }(\%)\end{array}$ \\
\hline & & \multicolumn{9}{|c|}{ Mean squares estimates ${ }^{1}$} \\
\hline Blocks & 4 & 10.6 & 0.704 & 0.674 & 0.081 & 8210 & 13.6 & 2.7 & 0.038 & 0.00031 \\
\hline Genotypes & 19 & $13.5^{\mathrm{ns}}$ & $6.504^{\mathrm{ns}}$ & $0.845^{\text {ns }}$ & $0.035^{\mathrm{ns}}$ & $605.2^{\text {ns }}$ & $45.5^{\mathrm{ns}}$ & $1.2^{\mathrm{ns}}$ & $0.014^{\mathrm{ns}}$ & $0.0013^{* *}$ \\
\hline Error & 76 & 14.7 & 8.680 & 0.652 & 0.036 & 408.1 & 29.0 & 1.5 & 0.016 & 0.0004 \\
\hline Statistics & & \multicolumn{9}{|c|}{ Estimates } \\
\hline Means & & 46.7 & 43.0 & 5.7 & 1.6 & 203.6 & 36.7 & 24.7 & 6.0 & 0.2048 \\
\hline \multicolumn{2}{|c|}{ Coefficient of experimental variation } & 8.2 & 6.8 & 14.2 & 11.9 & 9.9 & 14.7 & 4.9 & 2.3 & 10.0 \\
\hline Genetic par & & \multicolumn{9}{|c|}{ Estimates } \\
\hline \multicolumn{2}{|c|}{$\sigma_{F}^{2}$} & - & - & - & - & - & - & - & - & 0.00026 \\
\hline$\sigma_{g}^{2}$ & & - & - & - & - & - & - & - & - & 0.00018 \\
\hline $\mathrm{h}_{r}^{2}(\%)$ & & - & - & - & - & - & - & - & - & 67.7 \\
\hline $\mathrm{CV}_{\mathrm{g}}(\%)$ & & - & - & - & - & - & - & - & - & 6.5 \\
\hline $\mathrm{CV}_{\mathrm{g}} / \mathrm{CV}_{\mathrm{e}}$ & & - & - & - & - & - & - & - & - & 0.6 \\
\hline
\end{tabular}

${ }^{\text {ns }},{ }^{* *},{ }^{*}$ non-significant and significant at 1 and $5 \%$ probability by the $\mathrm{F}$ test, respectively. ${ }^{+}$significant at $5 \%$ probability by the $\mathrm{t}$ test.

TABLE 3 - Estimates for phenotypic (above the diagonal line) and genotypic coefficients of correlation between fruit height, mean weight of fruit, number of fruits $\mathrm{ha}^{-1}$ and fruit yield of custard apple progenies.

\begin{tabular}{lccccc}
\hline Characteristics & Fruit diameter & Fruit height & Mean weight of fruit & Number of fruits ha & Fruit yield $^{-1}$ \\
\hline Fruit diameter & - & $0.73^{* *}$ & $0.87^{*}$ & $0.06^{\mathrm{ns}}$ & $0.22^{\mathrm{ns}}$ \\
Fruit height & $0.85^{*}$ & - & $0.88^{*}$ & $-0.05^{\mathrm{ns}}$ & $0.10^{\mathrm{ns}}$ \\
Mean weight of fruit & $0.99^{*}$ & $0.94^{*}$ & - & $-0.08^{\mathrm{ns}}$ & $0.09^{\mathrm{ns}}$ \\
Number of fruits $\mathrm{ha}^{-1}$ & $0.08^{\mathrm{ns}}$ & $-0.11^{\mathrm{ns}}$ & $-0.16^{\mathrm{ns}}$ & - & $0.98^{*}$ \\
Fruit yield & $0.25^{\mathrm{ns}}$ & $0.03^{\mathrm{ns}}$ & $0.001^{\mathrm{ns}}$ & $0.99^{*}$ & -
\end{tabular}

*, ns significant and non-significant, respectively, at 5\% probability, by $\mathrm{t}$ test. 
TABLE 6 - Percentages (in relation to mean fruit mass) of pericarp, endocarp, seeds, and receptacle, in the fruit, and fruit volume, number of seeds/fruit, and total soluble solids content and total titratable acidity in the fruit pulp of custard apple tree half-sibling progenies.

\begin{tabular}{|c|c|c|c|c|c|c|c|c|c|}
\hline Progenies $^{2}$ & $\begin{array}{l}\text { Pericarp } \\
(\%)\end{array}$ & $\begin{array}{c}\text { Endocarp } \\
(\%)\end{array}$ & $\begin{array}{c}\text { Seeds } \\
(\%)\end{array}$ & $\begin{array}{c}\text { Receptacle } \\
(\%)\end{array}$ & $\begin{array}{c}\begin{array}{c}\text { Fruit } \\
\text { volume } \\
(\mathrm{ml})\end{array} \\
\end{array}$ & $\begin{array}{l}\text { Number of } \\
\text { seeds fruit }{ }^{-1}\end{array}$ & $\begin{array}{c}\text { Total soluble solids } \\
\text { content }\left({ }^{\circ} \mathbf{B}\right)\end{array}$ & pH & $\begin{array}{c}\text { Total } \\
\text { titratable } \\
\text { acidity }(\%)\end{array}$ \\
\hline $\mathrm{M}$ & 43.8 & 44.10 & 5.40 & 1.46 & 193.4 & 31 & 24.70 & 5.46 & $0.20 \mathrm{c}$ \\
\hline $\mathrm{A} 2$ & 46.9 & 42.93 & 5.63 & 1.53 & 200.6 & 36 & 24.44 & 5.55 & $0.16 \mathrm{c}$ \\
\hline A3 & 44.1 & 39.67 & 5.71 & 1.60 & 181.2 & 34 & 24.14 & 5.52 & $0.20 \mathrm{c}$ \\
\hline A4 & 47.3 & 42.29 & 5.54 & 1.51 & 205.8 & 35 & 24.17 & 5.52 & $0.19 \mathrm{c}$ \\
\hline A5 & 48.5 & 44.40 & 5.89 & 1.67 & 192.8 & 39 & 25.38 & 5.44 & $0.21 \mathrm{~b}$ \\
\hline A6 & 47.2 & 42.41 & 5.82 & 1.66 & 204.6 & 39 & 24.70 & 5.56 & $0.20 \mathrm{c}$ \\
\hline FE1 & 48.3 & 43.20 & 5.45 & 1.51 & 201.6 & 34 & 24.25 & 5.45 & $0.20 \mathrm{c}$ \\
\hline FE3 & 45.4 & 43.08 & 6.01 & 1.70 & 196.2 & 38 & 25.47 & 5.44 & $0.22 \mathrm{~b}$ \\
\hline FE4 & 47.9 & 43.52 & 6.46 & 1.49 & 214.2 & 41 & 25.73 & 5.43 & $0.25 \mathrm{a}$ \\
\hline FE5 & 46.9 & 43.24 & 5.59 & 1.54 & 202.6 & 38 & 25.00 & 5.51 & $0.21 \mathrm{c}$ \\
\hline FJ1 & 44.6 & 44.45 & 5.90 & 1.60 & 215.8 & 41 & 24.76 & 5.54 & $0.20 \mathrm{c}$ \\
\hline FJ2 & 48.5 & 42.68 & 5.43 & 1.74 & 179.2 & 31 & 24.27 & 5.59 & $0.20 \mathrm{c}$ \\
\hline JG1 & 47.4 & 42.00 & 5.33 & 1.57 & 219.2 & 39 & 24.37 & 5.52 & $0.19 \mathrm{c}$ \\
\hline JG2 & 47.6 & 42.84 & 5.58 & 1.55 & 211.4 & 38 & 24.95 & 5.49 & $0.20 \mathrm{c}$ \\
\hline JG3 & 48.5 & 44.58 & 5.97 & 1.73 & 202.6 & 36 & 25.30 & 5.50 & $0.21 \mathrm{c}$ \\
\hline JG4 & 48.0 & 42.43 & 5.68 & 1.69 & 205.0 & 36 & 24.74 & 5.48 & $0.23 \mathrm{~b}$ \\
\hline SM1 & 47.9 & 42.08 & 5.55 & 1.59 & 205.0 & 37 & 24.88 & 5.52 & $0.21 \mathrm{c}$ \\
\hline SM3 & 44.0 & 42.65 & 6.16 & 1.57 & 216.6 & 40 & 24.72 & 5.39 & $0.22 b$ \\
\hline SM7 & 44.9 & 44.39 & 6.37 & 1.63 & 215.2 & 40 & 23.92 & 5.57 & $0.19 \mathrm{c}$ \\
\hline SM8 & 46.8 & 43.48 & 4.71 & 1.52 & 209.4 & 33 & 24.48 & 5.44 & $0.20 \mathrm{c}$ \\
\hline Means & 47.7 & 43.02 & 5.71 & 1.59 & 203.6 & 37 & 24.72 & 5.49 & 0.21 \\
\hline $\mathrm{CV}, \%$ & 8.2 & 6.9 & 14.2 & 11.9 & 9.9 & 14.7 & 4.9 & 2.3 & 10.0 \\
\hline
\end{tabular}

${ }^{1}$ Means followed by the same letter are not different among themselves at 5\% probability, by Scott-Knott (1974) test.

${ }^{2}$ Source of progenies: $\mathrm{M}=$ city of Mossoró-RN; A = Ema Brandl's ranch, town of Aracati-CE; FE = UFERSA Experimental Farm, Mossoró-RN; FJ = Francisca Jales' ranch, Mossoró-RN; João Jerônimo's ranch, Mossoró-RN; SM = town of Serra do Mel-RN.

\section{CONCLUSIONS}

1 -The best progenies in terms of fruit yield (A3 and A4) are not necessarily the best for fruit dimensions and fruit mean weight (A2, FE4, JG1, JG2, SM1, SM7, and SM8). Progeny JG2 should be highlighted as promising in terms of yield and fruit size.

2 -The progenies are not different with regard to quality traits of fruits, but progeny FE4 presents higher total titratable acidity in the fruit pulp.

3 - Narrow-sense heritability estimates were high, with higher values for number of fruits $\mathrm{ha}^{-1}$ and fruit yield. Relatively high coefficients of genotypic variation were observed for number of fruits $\mathrm{ha}^{-1}$ and fruit yield, with lower values for the other characteristics. There were positive genotypic and phenotypic correlations between fruit diameter (FD) and fruit height, FD and mean fruit weight, and number of fruits ha- ${ }^{-1}$ and fruit yield.

\section{REFERENCES}

ASSOCIATION OF OFFICIAL AGRICULTURAL QUEMISTS. Official methods of analysis of the Association of Agricultural Chemists. $12^{\text {th }}$ ed.. Washington: AOAC, 1992. 1094p.
BANDEIRA, C.T., BRAGA SOBRINHO, R. Situação atual e perspectiva da pesquisa da agroindústria das anonáceas no Estado do Ceará. In: SÃO JOSÉ, A.R., SOUZA, I.V.B, MORAIS, O.M., REBOUÇAS, T.N.H (Ed.). Anonáceas: produção e mercado. Vitória da Conquista: UESB, 1997. p. 156-160.

CARVALHO, P. S. de; BEZERRA,J. E. F.; LEDERMAN, I. E.; ALVES, M. A.; MELO NETO, M. L. de. Avaliação de genótipos de pinheira (Annona squamosa L.) no Vale do Rio Moxotó III características de crescimento e produção de 1992 a 1997. Revista Brasileira de Fruticultura, Jaboticabal, v.22, n.1, p. 27-30, 2000.

Cruz, C.D. Programa Genes: estatística experimental e matrizes. Viçosa: UFV, 2006.285p.

CRUZ, C.D.; REGAZZI, A.J. Modelos biométricos aplicados ao melhoramento genético. Viçosa: UFV Imprensa Universitária, 1994.390p.

DANTAS E.P.; BEZERRA, J. E. F.; PEDROSA,A.C.; LEDERMAN, I. E. Características físico-químicas de frutos de pinheira (Anonna squamosa L.) oriundos de Pernambuco e Alagoas. Revista Brasileira de Fruticultura, Jaboticabal, v.13, n.1, p.111-116, 1991.

DAOYU, Z.; LAWES, G.S.; GORDON, I.L. Estimates of genetic variability and heritability for vegetative and reproductive characters of kiwifruit (Actinidia deliciosa). Euphytica, Dordrecht, v.124, n.1, p.93-98, 2002. 
DINESH, M.R.; YADAV, I.S. Half-sib analysis in guava (Psidium guajava). Indian Journal of Horticulture, New Delhi, v.55, n.1, p.20-22, 1998.

EMBRAPA. Centro Nacional de Pesquisa do Solo. Sistema brasileiro de classificação de solos. Brasília: Serviço de Produção de Informação, 1999. 412p.

FALCONER, D.S. Introduction to quantitative genetics. $3^{\text {rd }}$. ed. Essex: Longman Scientific and Technical, 1989. 389p.

FAO. Soil map of the world: revised legend. Rome: UNESCO, 1988.119p.

FREITAS, G.B. de.; COUTO,F.A.A. Situação e perspectiva do cultivo de anonáceas no Estado de Minas Gerais. In:SÃO JOSÉ, A.R.; SOUZA,I.V.B.; MORAIS, O.M.; REBOUÇAS, T.N.H. (Ed.). Anonáceas: produção e mercado. Vitória da Conquista: UESB, 1997. p.161-167.

GONÇALVES, P. de S.; BORTOLETTO, N.; SANTOS, W.R. dos; ORTOLANI, A.A.; GOTTARDI, M.V.C.; MARTINS, A.L.M. Avaliação genética de progênies em meios irmãos de seringueira em diferentes regiões do estado de São Paulo. Pesquisa Agropecuária Brasileira, Brasília, v.33, n.7, p.1085-1095, 1998.

HANSCHE, P.E.; HESSE, C.O.; BERES, V. Estimates of genetic and environmental effects on several traits in peach. Journal of the American Society for Horticultural Science, Alexandria, v.97, n.1, p.76-79, 1972.

HARDNER, C; WINKS, C.; STEPHENSON, R.; GALLAGHER, E. Genetic parameters for nut and kernel traits in macadamia. Euphytica, Dordrecht, v.117, n.1, p.151-161, 2001.

HOLSCHUH,H.J.; NARAIN,N.; VASCONCELOS,M.A.S.; SANTOS, C.M.G. Caracterização física de frutos de pinha oriundos do trópico do semi-árido da Paraíba. In: CONGRESSO BRASILEIRODE FRUTICULTURA, 9., 1987. Campinas. Anais... Campinas: SBF, 1988. v.2, p.669-673.

LEAL, F. Sugar apple. In: NAGY, S.; SHAW, P.E.; WARDOWSKI, W.F. (Ed.). Fruits of tropical and subtropical origin. Lake Alfred: FSS, 1990. 318p.

LEDERMAN, I.E.; BEZERRA, J.E.F. Situação atual e perspectivas de anonáceas no Estado de Pernambuco. In: SÃO JOSÉ, A.R.; SOUZA, I.V.B; MORAIS, O.M.; REBOUÇAS, T.N.H. (Ed.). Anonáceas: produção e mercado. Vitória da Conquista: UESB, 1997.p. 173-178.

MACHADO, G.M.E.; REGAZZI, A.J.; VIANA, J.M.S.; CRUZ, C.D; GRANATE, M.J. Estimação de parâmetros genéticos de uma população amazônica de cupuaçuzeiro (Theobroma grandiflorum (Willd ex Spreng) Schum). Revista Ceres, Viçosa, v.49, n.281, p.13-17, 2002.
MAIA, G. A.; MESQUITA FILHO, J. A. de; BARROSO, M.AT.; FIGUEREDO, R. W. de. Características físicas e químicas de ata. Pesquisa Agropecuária Brasileira, Brasília, v.21, n.4, p.10731076, 1986.

MANICA, I. Importância econômica. In: MANICA, I. Fruticultura: cultivo das anonáceas; ata-cherimóia-graviola. Porto Alegre: EVANGRAF, 1994. cap.1, p.1-2.

PURSEGLOVE, J.W. Tropical crops: dicotyledons. New York: John Wiley, 1968. v.II, 238p.

SÃO JOSÉ, A.R., SOUZA, I.V.B; MORAIS, O.M.; REBOUÇAS, T.N.H. (Eds.). Anonáceas: produção e mercado. Vitória da Conquista: Universidade Estadual do Sudoeste da Bahia, 1997. 308 .

SCOTT, A.J.; KNOTT, M.A. A cluster analysis method for grouping means in the analysis of variance. Biometrics, Washington, v.30, n.3, p.507-512, 1974.

REGO, F. A. O.; ALVES, R. E.; LIMA, E. D. P. A.; SILVA, H.; SILVA, A. Q. Caracterização física e química de diferentes frutos da família Annonaceae. In: CONGRESSO BRASILEIRO DE FRUTICULTURA, 10., 1989, Fortaleza. Resumos... Fortaleza: Sociedade Brasileira de Fruticulticultura, 1989. p.493-7

SOUSA, V.A.B., ARAÚJO, E.C.E., VASCONCELOS, L.F.L. Perspectivas do melhoramento de espécies nativas do nordeste brasileiro. In: CONGRESSO BRASILEIRO DE MELHORAMENTO DE PLANTAS, 1., 2001, Goiânia, GO. Anais... Goiânia: Embrapa-CNPAF/SBMP, 2001. CD-ROM.

VENCOVSKY, R. Genética quantitativa. In: KERR, W.E. Melhoramento e genética. São Paulo: Biblioteca Agronômica Melhoramentos, 1969. p.17-38.

VENCOVSKY, R.; BARRIGA, P. Genética biométrica no fitomelhoramento. Ribeirão Preto: Sociedade Brasileira de Genética, 1992. 486p.

ZAR, J.H. Biostatistical analysis. $4^{\text {th }}$ ed. Upper Saddle River: Prentice Hall, 1999. 663p. 